J. Lake Sci. (湖泊科学) , 2015, 27(2):200-207

http: //www.jlakes. org. E-mail : jlakes@niglas.ac.cn

(c) 2015 by Journal of Lake Sciences

\title{
洱海流域低污染水类型、污染负荷及分布”
}

白献宇, 胡小贞, 庞 燕

(中国环境科学研究院,北京 100012)

摘 要: 为科学、合理地评估湖泊流域低污染水的类型及其污染负荷, 以洱海流域为例, 系统研究低污染水的概念及类型, 确定了低污染水调查方法, 并分析了洱海流域低污染水的来源、类型、产生量、污染物量和分布特征. 结果表明, 洱海流域低污染 水主要包括污水处理厂处理尾水、城镇地表径流、农田排水 (含村落地表径流) 3 种主要类型,产生量为 $20069 \times 10^{4} \mathrm{~m}^{3} / \mathrm{a}$. 由低污染水带来的总氮 $(\mathrm{TN})$ 负荷为 $1393 \mathrm{t} / \mathrm{a}$, 总磷 (TP) 负荷为 $77 \mathrm{t} / \mathrm{a}$. 从空间分布上看, 洱海流域西部和北部片区低污染 水 TN、TP 负荷比例最大, 分别达到 $88 \%$ 和 $87 \%$, 因此应主要针对西部和北部片区特点制定洱海流域低污染水控制措施. 关键词: 洱海流域;低污染水类型;低污染水产生量;低污染水污染物量;空间分布特征

\section{Pollution load, distribution and characteristics of low-polluted water in Lake Erhai water- shed}

\author{
BAI Xianyu, HU Xiaozhen \& PANG Yan \\ (Chinese Research Academy of Environmental Sciences, Beijing 100012, P. R. China)
}

\begin{abstract}
In order to evaluate low-polluted water and its categories, this paper took Lake Erhai as a sample to systematically explore the concept, types and survey method of low-polluted water and to determine its pattern in source, discharge, pollution load and distribution. Results of this study revealed that the annual discharge of low-polluted water in the catchment is $20069 \times 10^{4} \mathrm{~m}^{3} / \mathrm{a}$, which mainly comes from three different sources: agricultural runoff, urban surface runoff and discharge from water treatment plant. Low-polluted water brings in 1393 ton total nitrogen (TN) and 77 ton total phosphorus (TP) annually. As for spatial distribution, the west and north part of Lake Erhai contain most TN and TP content, in percentages of $88 \%$ and $87 \%$, respectively. Therefore, water control action should be carried out according to the characteristics of west and north part of Lake Erhai.
\end{abstract}

Keywords: Lake Erhai watershed; low-polluted water type; low-polluted water output; low-polluted water pollution load; spatial distribution characteristics

在湖泊流域人湖地表径流中, 部分水质受到一定污染, 但主要水质指标又优于城镇污水处理厂污染 物排放标准, 无法排人污水处理厂进行处理, 但相对于湖泊水体来讲, 仍然为污染源, 不经处理直接人湖 又不能满足湖泊水质保护的要求, 这部分总氮浓度 $(\rho(\mathrm{TN}))$ 、总磷浓度 $(\rho(\mathrm{TP})) 、 \mathrm{COD}_{\mathrm{Cr}}$ 浓度 $\left(\rho\left(\mathrm{COD}_{\mathrm{Cr}}\right)\right)$ 相对较低的人湖水我们称为 “低污染水” ${ }^{[1]}$. 湖泊富营养化已经成为世界面临的重大水环境问题之一 ${ }^{[2-3]}$, 低污染水的问题应引起重视. 近年来, 随着我国湖泊治理力度的加强和湖泊治理新理念的提出, 低污染水 带来的污染问题越来越受到关注,低污染水治理已经成为湖泊流域点源和面源污染控制之后又一新的 挑战.

目前关于低污染水的研究, 主要集中于低污染水治理技术, 其中包括人工湿地技术 ${ }^{[4-7]}$ 、自然湿地技 术 $^{[8-9]}$ 、生态浮床技术 ${ }^{[10-11]}$ 、缓冲带技术 ${ }^{[12-14]}$ 等, 赵建伟等 ${ }^{[15-18]}$ 则开展了针对低污染水去除效率的材料及工 艺等方面的研究. 对低污染水进行有效治理, 首先应了解流域低污染水的类型及其分布规律, 目前鲜见该方 面的报道. 该文阐述了低污染水的概念与一般类型, 并以富营养化初期湖泊一一洱海及其流域为研究对象, 针对该流域以面源污染为主、低污染水问题突出的特征, 提出低污染水的调查和计算方法, 并开展了低污染

* 国家水体污染控制与治理科技重大专项 (2012ZX07105-003,2012ZX07105-002) 资助. 2014-01- 13 收稿;2014-08 16 收修改稿. 白献宇 (1980 ), 女, 高级工程师;E-mail: bjbxy226@163.com. 
水类型研究, 计算了流域不同类型低污染水的产生量、污染负荷及其空间分布, 分析了洱海流域的低污染水 特点与规律, 以期为科学、合理地制定全流域低污染水系统治理思路提供基础.

\section{1 低污染水的类型与特征}

低污染水包括经污水处理设施处理后但对湖泊水体来讲仍为污染源的尾水、地表径流以及污染物浓度 较低的农田排水、雨季村落地表径流等. 笔者在云南大理洱海和玉溪抚仙湖等多个湖泊开展的低污染水调 查和研究表明, 湖泊流域低污染水主要包括污水处理厂处理尾水、城镇地表径流、农田径流排水(含农村分 散性生活污水) 3 种类型.

\section{1 污水处理厂处理尾水}

比较《城镇污水处理厂污染物排放标准》( GB 18918－2002) 与《地表水环境质量标准》( GB 38382002 ), 可以发现, GB 18918-2002 中一级 A 标准的 $\rho(\mathrm{TN}) 、 \rho(\mathrm{TP})$ 分别是 GB 3838-2002 中 $\mathrm{V}$ 类水质标 准 (湖、库) 的 7.5 和 2.5 倍. GB 18918-2002 各级出 水与 $\mathrm{GB} 3838-2002$ 中 $\mathrm{V}$ 类水质标准 $\rho(\mathrm{TP})$ 、 $\rho\left(\mathrm{NH}_{4}^{+}-\mathrm{N}\right)$ 的比较如图 1 所示. 由图 1 可见, 城镇污水 处理厂达标排放的尾水中的营养物质, 对湖泊来讲仍 属污染源. 即使流域中的点源全部得到控制, 但由于 污水处理厂达标排放尾水仍为低污染水, 湖库、河流 地表水水质达标率仅为 $42 \% \sim 65 \%{ }^{[19]}$.

\section{2 城镇地表径流}

在面源污染中,城镇地表径流是仅次于农业面污 染源的第二大面污染源 ${ }^{[20]}$, 其主要来源于降水冲刷地表 垃圾和尘埃物质等, 其中悬浮颗粒物浓度 $(\rho(\mathrm{SS}))$ 、重金 属及碳氢化合物的含量等均与未经处理的城市污水基 本相同 ${ }^{[21]}$, 但在可生化性方面与城市污水存在巨大差

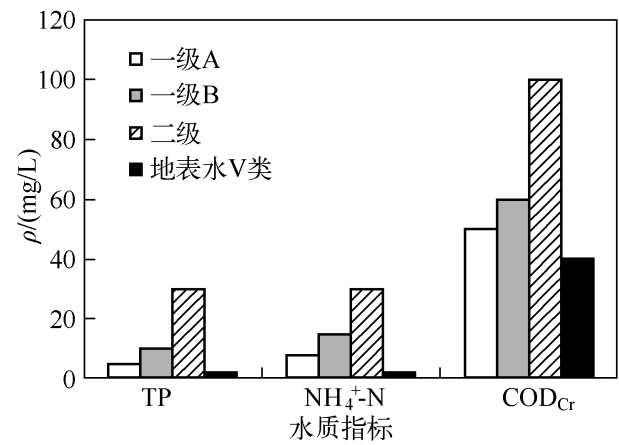

图 1 城镇污水处理厂尾水排放标准与地表水环境 质量标准比较 $(\rho(\mathrm{TP})$ 数值为标准值 $\times 10)$

Fig. 1 The concentration comparison between standards for the town sewage treatment plants tail water and the environmental quality standards for surface water 异, 采用常规的城市污水处理工艺处理是不合理的 ${ }^{[22]}$. 城镇地表径流污染具有随机性强、突发性强、径流量大的特 点. 北京市城市地表路面径流中 $\rho\left(\mathrm{COD}_{\mathrm{Cr}}\right) 、 \rho(\mathrm{TN}) 、 \rho(\mathrm{TP})$ 的平均值分别为 $116.24 、 12.35 、 0.457 \mathrm{mg} / \mathrm{L}^{[19]}$; 上 海市地表径流污染物中 $\rho\left(\mathrm{COD}_{\mathrm{Cr}}\right) 、 \rho(\mathrm{TN}) 、 \rho(\mathrm{TP})$ 的平均值分别为 $336 、 7.74 、 0.57 \mathrm{mg} / \mathrm{L}^{[23]}$; 昆明市地表径流 污染物中 $\rho\left(\mathrm{COD}_{\mathrm{Cr}}\right) 、 \rho(\mathrm{TN}) 、 \rho(\mathrm{TP})$ 平均浓度值分别为 $138.2 、 2.37$ 和 $0.43 \mathrm{mg} / \mathrm{L}^{[24]}$, 均高于地表水 $\mathrm{V}$ 类水 质. 因此城镇地表径流对湖泊、河流来讲构成威胁, 应将其纳人低污染水的范畴.

\section{3 农田径流排水(含农村分散性生活污水)}

受化肥施用量增加、施肥结构不合理等因素影响, 农田土壤中的氮、磷含量和氮、磷流失量也在不断增 加, 农田排放的营养物对水体的危害日益加剧 ${ }^{[25-28]}$, 由此所带来的一系列环境、经济问题已引起国内外有关 人士的极大关注.

从源水的性质分析, 农村分散性生活污水不应该纳人低污染水的范畴研究, 但是由于我国农田沟渠往 往汇人了周边农村的生活污水或相对清洁的生活杂排水, 因此农田径流排水不是单一的农业面源污染, 而 是集合了农村、农田复合污染性质的一类水. 虽然农村生活污水的有机物、氮磷营养物进入农业系统中会 有一定吸收、转化和降解, 但是高浓度的农村性分散生活污水一定程度上会加大径流中的污染物浓度. 农 村分散性生活污水可分为两类:一类为包括粪便水的污水,主要指使用水冲则所的情况; 另一类为清洁的 生活杂排水 (不包括粪便水), 主要指使用旱则的农村居民, 其产生的生活排水主要包括洗浴、洗衣和厨房 污水等. 农村分散性生活污水、村落地表径流与农田排水混合后进人河流或者湖泊, 因此该研究将分散性 农村生活污水、村落地表径流纳人农田径流排水进行研究. 农田排水沟渠是农田流失氮、磷进人受纳水体 前的运输通道 ${ }^{[29]}$. 由表 1 可见, 滇池流域农田排水沟渠水质变化较大,并且均高于 $\mathrm{V}$ 类水质标准. 
表 1 滇池流域农田径流水质状况

Tab. 1 The water quality of farmland runoff water in Lake Dianchi watershed

\begin{tabular}{cccc}
\hline 类型 & $\rho\left(\mathrm{COD}_{\mathrm{Cr}}\right) /(\mathrm{mg} / \mathrm{L})$ & $\rho(\mathrm{TN}) /(\mathrm{mg} / \mathrm{L})$ & $\rho(\mathrm{TP}) /(\mathrm{mg} / \mathrm{L})$ \\
\hline 滇池农田径流排水 $^{[30]}$ & $20.2 \sim 72.7$ & $4.0 \sim 33.5$ & $0.2 \sim 3.3$ \\
${\text { 滇池大清河流域农田沟渠 }{ }^{[31]}}^{1.4 \sim 62.3}$ & $2.3 \sim 172.7$ & $0.2 \sim 9.5$ \\
\hline
\end{tabular}

可见污水处理厂处理尾水、城镇地表径流、农田排水 (含村落地表径流) 等水体中污染物的质量浓度仍 远高于地表水环境质量 $\mathrm{V}$ 类水质标准,对于湖泊水体来说仍然属于污染源.

\section{2 研究方法}

\section{1 洱海流域概况}

洱海地处云南省大理白族自治州境内, 流域面积 $2565 \mathrm{~km}^{2}$, 湖面面积 $249.4 \mathrm{~km}^{2[32]}$, 境内有弥苴河、永安 江、罗时江、波罗江及苍山十八溪等大小河溪 117 条和洱海、茈碧湖、海西海、西湖等湖泊与水库. 洱海流域 属中亚热带西南季风气候带, 全年有干湿季之别而无四季之分, 年平均气温为 $15.5^{\circ} \mathrm{C}$, 全年平均最高气温 $22.2^{\circ} \mathrm{C}$, 最低气温 $10.2^{\circ} \mathrm{C}$. 雨量充沛, 全年降雨量为 $1000 \sim 1100 \mathrm{~mm}$, 但分布不均, $95 \%$ 的降雨集中在 $5-10$ 月的雨季, 2010 年和 2011 年洱海水质状况见表 $2^{[33]}$.

表 2 洱海水质状况

Tab. 2 The water quality of Lake Erhai

\begin{tabular}{cccccc}
\hline 年份 & 水域功能 & 水质综合评价 & 透明度 $/ \mathrm{m}$ & 营养状态指数 & 主要污染指标 \\
\hline 2010 年 & II & III & 1.68 & 41.23 & 溶解氧、TN \\
2011 年 & II & III & 1.81 & 38.77 & TN、TP \\
\hline
\end{tabular}

\section{2 低污染水调查流程}

流域低污染水污染源调查主要包括资料收集、采样分析和现场调查, 调查内容包括: (1) 运行或在建的城 镇污水处理厂数量、分布、处理规模、实际处理能力等; (2) 流域农田面积、类型、种植习惯、主要种植作物及施 肥方法等; (3) 流域农村人口、人均用水量、排水现状及特点、农村污水处理现状; (4) 流域城镇面积、人口密 度、降雨资料等. 基于以上调查资料, 根据污水处理厂处理尾水、农田排水、城镇地表径流等水质研究及 GB 3838-2002、GB 18918-2002 等标准限值, 计算洱海流域不同类型的低污染水产生量及污染物量. 低污染水 调查流程见图 2.

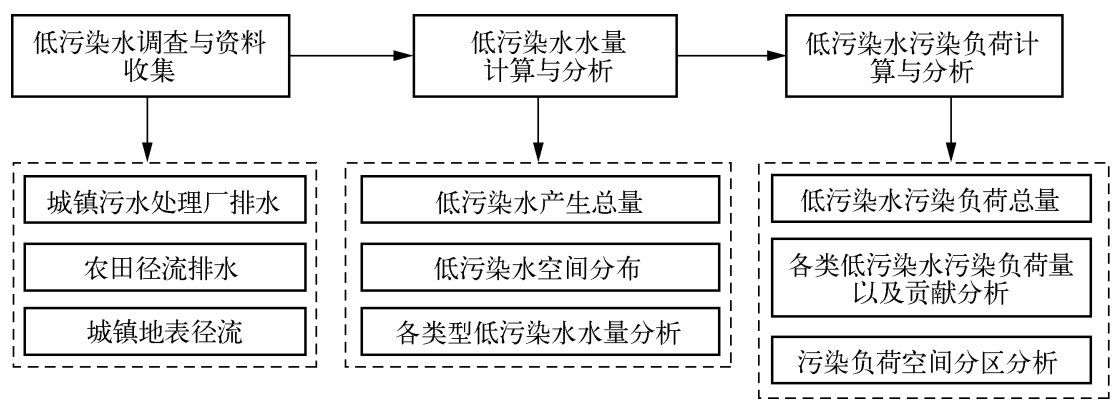

图 2 低污染水调查流程

Fig. 2 The investigation process of low-polluted water 


\section{3 结果与分析}

\section{1 污水处理厂尾水}

根据洱海流域已建或在建 (已经发挥或即将发挥效益) 的污水处理厂的数量和处理规模, 计算污水处理 厂处理尾水水量,并按照 GB 18918-2002 中出水标准计算污染负荷量：

$$
L_{\mathrm{W} i}=10^{-6} Q_{\mathrm{W}} \cdot C_{\mathrm{W} i}
$$

式中, $L_{\mathrm{W} i}$ 为 $i$ 污染物污水处理厂尾水污染负荷 $(\mathrm{t} / \mathrm{a}), Q_{\mathrm{W}}$ 为流域城镇污水处理规模 $\left(\mathrm{m}^{3} / \mathrm{a}\right), C_{\mathrm{W} i}$ 为城镇污水 处理厂出水中 $i$ 污染物的质量浓度 $(\mathrm{mg} / \mathrm{L})$, 根据洱海流域污水处理厂出水现状及出水水质要求, 大渔田污 水处理厂建设时间较早,出水达到 GB 18918-2002 的二级标准,近些年新建设的污水处理厂出水要求达到 一级 $\mathrm{A}$ 标准,但鉴于大渔田污水处理厂较大的处理规模和现状出水水质,并考虑污水处理厂的提标升级趋 势,综合考虑该研究中取相应 GB 18918-2002 中一级 B 标准,即 TN 为 $20 \mathrm{mg} / \mathrm{L}, \mathrm{TP}$ 为 $1 \mathrm{mg} / \mathrm{L}$.

洱海流域已经逐步建立城镇、集镇两级污水收集处理系统,其中城市污水处理厂主要处理大理市市区 和洱源县县城的生活污水, 共计有 3 座, 分别为大渔田污水处理厂、庆中污水处理厂和洱源县县城污水处理 厂. 洱海流域已经运行或即将投人运行的集镇污水处理厂有 10 座, 大理市有上关镇、喜洲镇、周城镇、双廊 镇和海东镇 5 座污水处理厂, 洱源县有牛街乡、凤羽镇、右所集镇、三营镇、邓川镇 5 座污水处理厂.

洱海流域城镇污水处理厂处理能力可达 $3194 \times 10^{4} \mathrm{~m}^{3} / \mathrm{a}$, 其中城市生活污水处理厂为 $2445 \times 10^{4} \mathrm{~m}^{3} / \mathrm{a}$, 集镇污水处理厂为 $748 \times 10^{4} \mathrm{~m}^{3} / \mathrm{a}$, 达标排放尾水中 TN 负荷量为 $639 \mathrm{~m}^{3} / \mathrm{a}$, TP 负荷量为 $48 \mathrm{~m}^{3} / \mathrm{a}$.

\section{2 农田径流排水(含村落地表径流)}

农田径流排水量涉及土地利用类型、作物种植、降雨、农田灌溉等较多因素，目前没有统一的计算方法， 该文采用了根据降雨期农田产流量和灌溉期农田排水量计算与根据稻季径流水量计算 2 种方法, 将计算结 果进行对比和验证分析,粗略估算流域农田径流产生的水量.

$$
\begin{aligned}
& Q_{\mathrm{N}}=\max \left(Q_{\mathrm{J}}, Q_{\mathrm{G}}\right) \\
& Q_{\mathrm{J}}=10^{-3} R \cdot A \cdot a \\
& Q_{\mathrm{G}}=M_{\mathrm{G}} \cdot A \cdot b \\
& Q_{\mathrm{N}}=10^{-4} \mathrm{D} \cdot A
\end{aligned}
$$

式中, $Q_{\mathrm{N}}$ 为农田径流排水量 $\left(\mathrm{m}^{3} / \mathrm{a}\right), Q_{\mathrm{J}}$ 为降雨期农田产流量 $\left(\mathrm{m}^{3} / \mathrm{a}\right), Q_{\mathrm{G}}$ 为灌溉期农田排水量 $\left(\mathrm{m}^{3} / \mathrm{a}\right), R$ 为 降雨量 $(\mathrm{mm}), A$ 为农田面积 $\left(\mathrm{m}^{2}\right), a$ 为农田产流系数 $(\%), M_{\mathrm{G}}$ 为农田平均灌溉用水量 $\left(\mathrm{m}^{3} / \mathrm{m}^{2}\right), D$ 为稻季径 流水量 $\left(\mathrm{m}^{3} / \mathrm{hm}^{2}\right), b$ 为灌溉水利用系数.

降雨期农田径流排水量主要取决于降雨量和降雨强度, 滇池研究表明, 在降雨量为 $80 \mathrm{~mm}$ 的条件下, 农 田径流排水量是降雨量的 $53.52 \%{ }^{[34]}$, 贺宝根等 ${ }^{[35]}$ 的研究表明, 不同降雨量的情况下农田氮素流失量的差 异较大. 通过分析洱海流域降雨资料, 实际达到 $80 \mathrm{~mm}$ 降雨的现象并不多见, 故该研究农田径流排水量按照 降雨量的 $40 \%$ 估算; 灌溉期农田排水量采用农田平均灌溉用水量 $0.672 \mathrm{~m}^{3} / \mathrm{m}^{2[36]}$ 计算.

水稻是洱海流域主要的大春种植作物, 按照郭智等 ${ }^{[37]}$ 的研究采用稻季径流水量为 $5705.55 \mathrm{~m}^{3} / \mathrm{hm}^{2}$ 估算.

农田径流污染负荷的计算:

$$
L_{\mathrm{N} i}=10^{-6} Q_{\mathrm{N}} \cdot C_{\mathrm{N} i}
$$

式中, $L_{\mathrm{N} i}$ 为 $i$ 污染物农田径流污染负荷 $(\mathrm{t} / \mathrm{a}), C_{\mathrm{N} i}$ 为农田径流 $i$ 污染物的质量浓度 $(\mathrm{mg} / \mathrm{L})$.

首先采用年均流失量框定范围值, 并通过全国污染源普查的系数方法进行数据的具体化. 第一次全国 污染源普查中农业污染源的肥料流失系数中施肥量的基本参数信息与洱海流域实际差距较大, 因此在实际 计算中需要进行系数修正. 
根据降雨期农田产流量与灌溉期农田排水量的计算方法, 洱海流域每年农田径流排水量在降雨期为 $1.0 \times 10^{8} \mathrm{~m}^{3} / \mathrm{a}$, 农业灌溉产生量为 $0.7 \times 10^{8} \mathrm{~m}^{3} / \mathrm{a}$, 则洱海流域每年农田径流排水估算为 $1.7 \times 10^{8} \mathrm{~m}^{3} / \mathrm{a}$; 根 据稻季径流水量计算,洱海流域每年农田径流排水量为 $1.4 \times 10^{8} \mathrm{~m}^{3} / \mathrm{a}$. 两种计算方法都有一定的局限性,有 待于进一步研究, 该研究考虑到方法不同引起的误差, 按 $1.5 \times 10^{8} \mathrm{~m}^{3} / \mathrm{a}$ 进行研究.

农田降雨径流污染负荷估算难度很大, 参考滇池流域农田污染物年均流失量, TN 为 $5.07 \sim 113.16 \mathrm{~kg} / \mathrm{hm}{ }^{2}, \mathrm{TP}$ 为 $0.15 \sim 10.14 \mathrm{~kg} / \mathrm{hm}^{2[38]}$, TN 负荷量为 $128 \sim 2866 \mathrm{t} / \mathrm{a}$, TP 负荷量为 $3.8 \sim 256 \mathrm{t} / \mathrm{a}$, 采用第一次全国污染源普查系 数研究, 由于洱海流域种植模式施肥量约为污染源普查测算系数基础的 2 倍, 通过修正, TN 为 $604 \mathrm{t} / \mathrm{a}, \mathrm{TP}$ 为 $18 \mathrm{t} / \mathrm{a}$.

\section{3 城镇地表径流}

采用城市综合径流系数计算城镇范围的总降雨量,并根据初期径流的比例计算.

$$
Q_{\mathrm{C}}=10^{3} \mathrm{~A} \cdot P \cdot c
$$

式中, $Q_{\mathrm{C}}$ 为城镇地表径流量 $\left(\mathrm{m}^{3} / \mathrm{a}\right), A$ 为城镇建成区面积 $\left(\mathrm{km}^{2}\right), P$ 为城镇年降雨量 $(\mathrm{mm}), c$ 为综合径流 系数.

由于洱海流域涉及的城镇以中小规模的城镇居多, 根据《室外排水设计规范》, 按城市建筑稀疏区计, 综 合径流系数取 0.40 . 但在一场降雨过程中, 占总径流 $20 \%$ 或 $25 \%$ 的初期径流, 冲刷排放了约 $50 \%$ 的总径流 污染负荷 ${ }^{[39]}$, 因此该研究按照 $25 \%$ 的初期径流比例进行研究.

城镇地表径流污染物量的计算有 2 种方法,一种为按水量与浓度计算, 另一种采用单位负荷法 ${ }^{[40]}$. 计算 公式为:

$$
L_{\mathrm{C} i}=10^{-6} Q_{\mathrm{C}} \cdot C_{\mathrm{C} i}
$$

式中, $L_{\mathrm{C} i}$ 为城镇地表径流污染负荷量 $(\mathrm{t} / \mathrm{a}), Q_{\mathrm{C}}$ 为城镇地表径流量 $\left(\mathrm{m}^{3} / \mathrm{a}\right), C_{\mathrm{C} i}$ 为城镇地表径流 $i$ 污染物的质 量浓度 $(\mathrm{mg} / \mathrm{L})$.

其中水量与浓度计算方法中浓度值参照北京市 ${ }^{[22]}$ 、上海市 ${ }^{[23]}$ 、西安市 ${ }^{[41]}$ 和天津城区 ${ }^{[42]}$ 的地表路面径 流污染物浓度的研究分析,该研究采用城镇地表径流中 TN 为 $8 \mathrm{mg} / \mathrm{L}$ 和 TP 为 $0.6 \mathrm{mg} / \mathrm{L}$ 计算.

洱海流域城镇面源来源于大理市市区、洱源县县城、大理经济技术开发区和大理古城 (大理镇)、凤仪 镇、喜洲镇、上关镇等乡镇人口聚居区, 面积约 $71 \mathrm{~km}^{2}$. 参照下关镇人口密度, 城镇人口密度按 1500 人 $/ \mathrm{km}^{2}$ 计. 洱海流域城镇范围的总降雨量为 $7.5 \times 10^{7} \mathrm{~m}^{3} / \mathrm{a}$, 城镇地表径流水量为 $1.875 \times 10^{7} \mathrm{~m}^{3} / \mathrm{a}$, 采用水量与水 质计算方法, TN 为 $150 \mathrm{t} / \mathrm{a}, \mathrm{TP}$ 为 $11 \mathrm{t} / \mathrm{a}$; 采用单位负荷法计算, TN 为 $144 \mathrm{t} / \mathrm{a}$, TP 为 $20 \mathrm{t} / \mathrm{a}$. 两种方法计算得 到的数值比较一致,该研究中采用 TN 为 $150 \mathrm{t} / \mathrm{a}, \mathrm{TP}$ 为 $11 \mathrm{t} / \mathrm{a}$.

\section{4 低污染水产生量与污染负荷分析}

经计算,洱海流域低污染水主要来源于农田径流排水和污水处理厂处理尾水. 洱海流域低污染水 TN、 TP 负荷均主要来自农田径流排水和污水处理厂处理尾水 (表 3). 虽然低污染水在人湖过程中通过河流、农 田、湖库、自然湿地、湖滨植被等自然系统会有一定的净化和削减作用, 但从流域污染物总量控制与污染物 目标削减的角度考虑, 低污染水必须引起足够的重视.

表 3 洱海流域低污染水产生量与污染负荷量

\begin{tabular}{|c|c|c|c|c|c|c|}
\hline \multirow{2}{*}{ 类别 } & \multicolumn{2}{|l|}{ 水量 } & \multicolumn{2}{|l|}{$\mathrm{TN}$} & \multicolumn{2}{|l|}{$\mathrm{TP}$} \\
\hline & 产生量/ ( × $\left.10^{4} \mathrm{~m}^{3} / \mathrm{a}\right)$ & 比例 $/ \%$ & 产生量/(t/a) & 比例/\% & 产生量/(t/a) & 比例 $/ \%$ \\
\hline 污水处理厂处理尾水 & 3194 & 15.9 & 639 & 44.1 & 48 & 62.3 \\
\hline 农田径流排水 & 15000 & 74.7 & 604 & 45.6 & 18 & 23.4 \\
\hline 城镇地表径流 & 1875 & 9.4 & 150 & 10.3 & 11 & 14.3 \\
\hline 合计 & 20069 & 100 & 1393 & 100 & 77 & 100 \\
\hline
\end{tabular}

Tab. 3 The output and pollution load of low-polluted water of Lake Erhai watershed 


\section{5 低污染水空间分布分析}

根据洱海流域地形地貌、污染源分布特征以及河流水系的分布, 将洱海流域分为 4 大片区, 分别为北部 片区、南部片区、东部片区和西部片区, 各区域低污染水的产生量及特征见表 4. 由表 4 可见, 洱海流域北部 片区低污染水产生量最大, 约占低污染水总量的 $48.6 \%$, 其次为西部片区 ( $40.2 \%)$, 东部和南部片区低污染 水量仅占低污染水总量的 $11.2 \%$.

表 4 洱海流域分区特征与低污染水产生量

Tab. 4 The subarea characteristics and output of low-polluted water of Lake Erhai watershed

\begin{tabular}{|c|c|c|c|c|c|c|c|}
\hline 区域名称 & $\begin{array}{l}\text { 面积/ } \\
\mathrm{km}^{2}\end{array}$ & 区域范围 & $\begin{array}{c}\text { 人口/ } \\
\left(\times 10^{4} \text { 人 }\right)\end{array}$ & $\begin{array}{c}\text { 农田面积/ } \\
\mathrm{km}^{2}\end{array}$ & $\begin{array}{l}\text { 畜禽养 } \\
\text { 殖量/ } \\
\text { 头 }\end{array}$ & $\begin{array}{l}\text { 低污染水 } \\
\text { 产生量/ } \\
\left(\times 10^{4} \mathrm{~m}^{3} / \mathrm{a}\right)\end{array}$ & 低污染水分布与人湖特征 \\
\hline 北部片区 & 1188.18 & $\begin{array}{l}\text { 含上关、邓川、 } \\
\text { 右所、凤羽、茈 } \\
\text { 碧湖、三营、牛 } \\
\text { 街 } 7 \text { 个乡镇 }\end{array}$ & 31.7 & 215 & 181005 & 9750 & $\begin{array}{l}\text { 人湖径流量占到 } 50 \% \text { 以上; “北三 } \\
\text { 江” 水系为主的人湖河流是污染物 } \\
\text { 的主要输送通道; 畜禽养殖数量 } \\
\text { 多,规模大 }\end{array}$ \\
\hline 南部片区 & 429.66 & $\begin{array}{l}\text { 含凤仪镇 } 1 \text { 个 } \\
\text { 乡镇 }\end{array}$ & 6.9 & 18 & 8040 & 1441 & $\begin{array}{l}\text { 城镇生活和工业污染为主; 以波罗 } \\
\text { 江水系为主的人湖河流是污染物 } \\
\text { 的主要输送通道 }\end{array}$ \\
\hline 东部片区 & 277.02 & $\begin{array}{l}\text { 含海东、挖色、 } \\
\text { 双廊 } 3 \text { 个乡镇 }\end{array}$ & 14.1 & 19 & 19756 & 810 & $\begin{array}{l}\text { 地势较陡, 区域空间较小; 人口与 } \\
\text { 农田分布比例较低; 面山破坏和较 } \\
\text { 严重水土流失; 以山菁为主的人湖 } \\
\text { 河流及地表漫流是人湖主要途径 }\end{array}$ \\
\hline 西部片区 & 425.27 & $\begin{array}{l}\text { 含喜洲、湾桥、 } \\
\text { 银桥、大理、下 } \\
\text { 关 } 5 \text { 个乡镇 }\end{array}$ & 29.8 & 103 & 39847 & 8068 & $\begin{array}{l}\text { 洱海流域人口和农田的主要分布 } \\
\text { 区域之一; 苍山十八溪为主的人 } \\
\text { 湖河流是污染物的主要输送通道 }\end{array}$ \\
\hline
\end{tabular}

洱海流域低污染水主要集中于北部片区和西部片区, 两片区水量、TN 和 TP 的产生量分别占流域的 $89 \% 、 88 \%$ 和 $87 \%$ （图 3). 洱海流域低污染水的治理要立足于流域层面, 以减少低污染水的产生量和构建沿 程截留净化系统为出发点, 分类分片治理. 洱海北部片区和西部片区污染源集中, 污染源类型多, 河湖水系 复杂, 污染物产排量大, 是洱海流域低污染水净化的重点区域, 要着重进行弥苴河、罗时江、永安江 3 条主要 人湖河流的污染治理和生态修复、构建库塘低污染水净化系统; 洱海西部片区, 重点进行十八溪的污染治理 和生态修复; 洱海东部片区主要是控制水土流失带来的低污染水; 南部片区为大理市区和开发区所在地, 低 污染水系统重点进行城市地表径流和污水处理厂排水的净化处理.

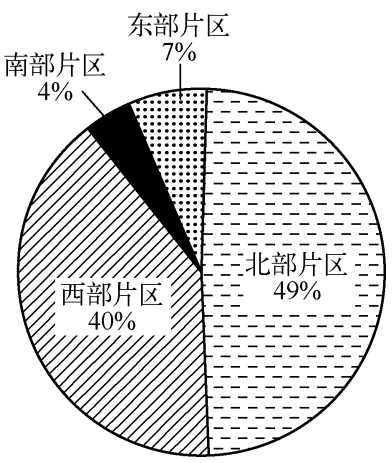

水量

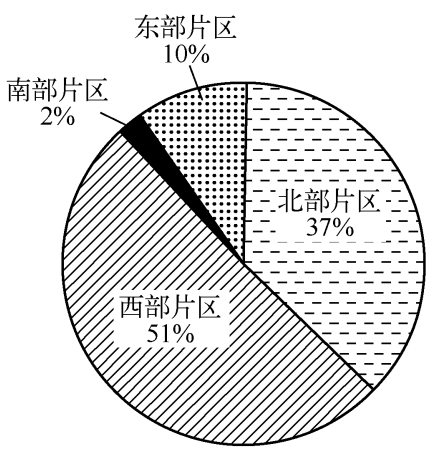

TN

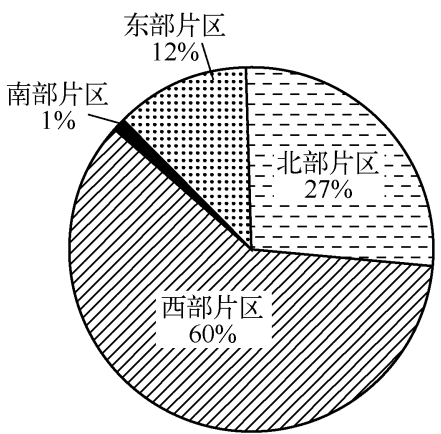

$\mathrm{TP}$

图 3 洱海流域低污染水空间分布

Fig. 3 The space distribution of low-polluted water of Lake Erhai watershed 


\section{4 结论}

1) 洱海流域低污染水主要来源于污水处理厂处理尾水、城镇面源、农田径流排水(含村落地表径流) 3 种主要类型, 低污染水产生量为 $20069 \times 10^{4} \mathrm{~m}^{3} / \mathrm{a}$, 其中农田径流排水产生的水量最大, 占到流域低污染水产 生量的 $74.7 \%$.

2) 洱海流域低污染水中 TN 负荷量为 $1393 \mathrm{t} / \mathrm{a}$, TP 负荷量为 $77 \mathrm{t} / \mathrm{a}$. 污水处理厂处理尾水中 TN 和 TP 占 到流域低污染水的 $44.1 \%$ 和 $62.3 \%$; 这个结论值得进一步研究和分析, 但同时也表明城镇污水处理厂处理 尾水对湖泊水质具有较大的影响.

3 ) 洱海流域低污染水主要来源于洱海北部和西部片区, 低污染水产生量占到整个流域低污染水的 $89 \%$, TN 和 TP 产生量分别占到整个流域的 $88 \%$ 和 $87 \%$, 其中 TN 和 TP 的贡献比率均为西部片区高于北部 片区.

4) 本研究中农田径流排水浓度和城镇地表径流浓度的取值分析还不成熟, 只能作为粗略估算, 在流域 治理的大尺度范围内如何准确取值计算,值得进一步研究和分析.

\section{5 参考文献}

[ 1 ] 金相灿, 胡小贞. 湖泊流域清水产流机制修复方法及其修复策略. 中国环境科学, 2010,30(3):374-379.

[ 2 ] Mccomb AJ. Eutrophic shallow estuaries and lagoons. Boca Raton, FL: CRC Press, 1995:126-127.

[ 3 ] Livingstoni RJ. Eutrophication processes in coastal systems: origin and succession of plankton blooms and effects on secondary production in gulf coast estuaries. Boca Raton, FL: CRC Press,2002:145-147.

[ 4 ] 黄德锋, 李 田,陆 斌. 复合垂直流人工湿地污染物去除及微生物群落结构的 PCR-DGGE 分析. 环境科学研究, $2007,20(6): 137-141$.

[ 5 ] Mitsch WJ, Lefeuvre JC, Bouchard V. Ecological engineering applied to river and wetland restoration. Ecological Engineering, 2002, 18 :529-541.

[ 6 ] Luederitz V, Eckert E, Lange-Weber M et al. Nutrient removal efficiency and resource economics of vertical flow and horizontal flow constructed wetlands. Ecological Engineering, 2001, 18(2):157-171.

[ 7 ] 陈泽涛, 易 皓, 庞志华等. 脉冲垂直流人工湿地处理污染河水的试验研究. 中国给水排水, 2010, (5):77-83.

[ 8 ] 张永泽,王 垣. 自然湿地生态恢复研究综述. 生态学报,2001,21(2):309-314.

[9] 杨永兴. 国际湿地科学研究的主要特点、进展与展望. 地理科学进展,2002,21(2):111-120.

[10] Li M, Wu YJ, Yu ZL et al. Nitrogen removal from eutrophic water by floating-bed-grown water spinach( Ipomoea aquatica Forsk. ) with ion implantation. Water Research, 2007, 41:3152-3158.

[11] Skinner K, Wright N, Porter-Goff E. Mercury uptake and accumulation by four species of aquatic plants. Environmental Pollution, 2007, 145(1):234-237.

[12] 黄廷林,戴栋超, 王 震等. 漂浮植物修复技术净化城市河湖水体试验研究. 地理科学进展, 2008,25(6):62-67.

[13] 杨林章, 周小平, 王建国等. 用于农田非点源污染控制的生态拦截型沟渠系统及其效果. 生态学杂志, 2005,24 (11) : 1371-1374.

[14] 邓红兵,王青春,王庆礼等. 河岸植被缓冲带与河岸带管理. 应用生态学报,2001,12(6):951-954.

[15] 赵建伟,单保庆, 尹澄清. 生态滤池在低污染水体治理中的应用及其季节效应. 中国给水排水, 2010,26(11): 21-23.

[16] 陈建刚. 粉煤灰合成沸石固磷机制及固磷能力强化技术研究 [学位论文]. 上海: 上海交通大学, 2007.

[17] 王远红, 曹文平, 张永明等. 竹丝复合生物反应器处理城市景观水体. 水处理技术, 2008, 34(7):25-28.

[18］蔡珉敏.复合垂直流人工湿地对低污染水中氮的去除研究 [ 学位论文]. 北京: 北京科技大学,2009.

[19] 韩 冰,王效科,欧阳志云. 北京市城市非点源污染特征的研究. 中国环境监测, 2005,21(6) :63-65.

[20] Deletic AB, Maksimovic CT. Evaluation of water quality factors in storm runoff from paved areas. Journal of Environment Engineering, 1998, 124(9) : 869-879.

[21] Ellis KV, White G, Warn AE. Surface water pollution and its control. England: Macmillan Publishers Ltd. , 1989: 268-270. 
[22] 王彦红, 韩 芸,彭党聪. 城市雨水径流水质特性及分析. 环境工程,2006,26(3):84-85.

[23] 林莉峰.上海市城区地表径流污染特性调查与研究 [ 学位论文].上海: 同济大学,2006:55-59.

[24] 谷 雨,张乃明. 昆明主城区城市地表径流污染特征分析. 环境工程学报,2013,7(7):2587-2595.

[25] Cameira MR, Fernando RM, Pereira LS. Monitoring water and $\mathrm{NO}_{3}-\mathrm{N}$ in irrigated maize fields in the Sorraia watershed, Portugal. Agricultural Water Management, 2003, 60(3) :199-216.

[26] Cao ZH. Environmental issues related to chemical fertilizer use in China. Pedosphere, 1996, 6(4):289-303.

[27] Ekholm P, Kallio K, Salo S et al. Relationship between catchment characteristics and nutrient concentrations in an agricultural river system. Water Research, 2000, 34(15):3709-3716.

[28 ] Sharpley AN, William JG, Folmar G et al. Sources of phosphorus exported from an agricultural watershed in Pennsylvania. Agricultural Water Management, 1999, 41:77-89.

[29] Owens LB, Van Keuren RW, Edward WM. Budgets of Non-nitrogen nutrients in a high fertility pasture system. Agriculture, Ecosystems and Environment, 1998, 70(1):7-18.

[30］卢海凤. 水平与垂直复合流土地慢渗对农田径流污水脱氮除磷效果研究 [学位论文]. 北京: 中国农业大学,2007: $19-22$.

[31］刘忠翰,彭江燕. 滇池流域农业区排水水质状况的初步调查. 云南环境科学, 1997,16(2):6-9.

[32］尹延震,储昭升,赵 明等. 洱海湖滨带水质的时空变化规律. 中国环境科学,2011,31(7):1192-1196.

[33] 云南省环境保护厅. 九湖水质及治理公告 $[\mathrm{EB} / \mathrm{OL}]$. 昆明:云南省环境保护厅,2012[2012-10-01]. http://www. ynepb. gov. cn/gyhp/jhszjzlgg/.

[34] 王 涛. 滇池流域施用有机肥农田氮磷流失模拟研究 [学位论文]. 北京: 中国农业科学院,2007:21-23.

[35] 贺宝根, 周乃戬, 胡雪峰等. 农田降雨径流污染模型探讨一以上海郊区农田氮素污染模型为例. 长江流域资源与 环境, 2001,(2):159-164.

[36] 云南省水利厅. 2010 年云南省水资源公报 [EB/OL]. 昆明: 云南省水利厅, 2011 [2012 - 10 - 01]. http://www. ynswj. gov. cn/article_show. asp? ID $=4210$.

[37] 郭 智,肖 敏,陈留根等. 稻麦两熟农田稻季养分径流流失特征. 生态环境学报,2010,19(7):1622-1627.

[38] 程文娟,史 静,夏运生等. 滇池流域农田土壤氮磷流失分析研究. 水土保持学报,2008,22(5):52-55.

[39］赵剑强. 城市地表径流污染与控制. 北京:中国环境科学出版社,2002:57-84.

[40］金相灿. 湖泊富营养化控制和管理技术. 北京:化学工业出版社,2001:15-30.

[41] 车 伍,刘 燕,李俊奇. 国内外城市雨水水质及污染控制. 给水排水,2003,29(10):38-41.

[42] 张 娜,赵乐军, 李铁龙等. 天津城区道路雨水径流水质监测及污染特征分析. 生态环境学报, 2009,18 (6): 2127-2131. 